\title{
Optimisation of process for pangasius surimi: effect of mince to water ratio on quality of surimi
}

\author{
M. A. HASSAN, M. K. CHOUKSEY, K. A. MARTIN XAVIER, G. VENKATESWARLU* \\ AND AMJAD BALANGE \\ ICAR-Central Institute of Fisheries Education, Versova, Mumbai - 400061, Maharashtra, India \\ *Education Division, Indian Council of Agricultural Research, New Delhi - 110 001, India \\ e-mail:amjadbalange@cife.edu.in,mdaman.hassan@gmail.com
}

\begin{abstract}
Pangasius (Pangasianodon hypophthalmus Sauvage, 1878) is an important food fish species in south-east Asian countries which is cultivated on a large scale throughout the region and has been introduced widely outside of its native range. Production of this species from India is also increasing tremendously. However, the species produced from Indian environment has meat discoloration issue which reduces its economic value. Therefore, there is need for alternate methods of its utilisation and surimi preparation from the species can be one of the best alternatives. Therefore, attempts were made in the present study to optimise the process of surimi preparation from pangasius. Effect of different mince to water ratios i.e., 1:1, 1:2, 1:3 and 1:4 with 3 washing cycles on the quality of pangasius surimi was investigated. From the results, it was found that among the different mince to water ratios, 1:3 and 1:4 were better as these gave high gel strength and low expressible moisture to the surimi as compared to other ratios. SDS-PAGE study revealed disappearance of myosin heavy chain (MHC) in the surimi obtained with ratios of 1:3 and 1:4. Whiteness of surimi improved with increase in mince: water ratio. Sensory evaluation indicated highest overall acceptability for surimi obtained with mince:water ratios of 1:3 and 1:4. However, there was no significant difference between the quality of surimi obtained with mince: water ratios of $1: 3$ and 1:4.
\end{abstract}

Keywords: Gel strength, Mince:water ratio, Pangasius, SDS-PAGE, Surimi

\section{Introduction}

Fish is the cheapest source of good quality protein readily available throughout the world. Presently, consumer demand is increasing for ready-to-eat/ready-to-cook fish products with less fat and salt which finally lead to value addition. Surimi is used as a base material for preparation of value added fish products. It is a stabilised myofibrillar protein obtained from mechanically deboned fish mince that has been washed, refined and mixed with cryoprotectants for better frozen shelf life (Lee, 1986; Ofstad et al., 1990). While preparing surimi, washing of the minced fish meat is a very important step, which helps to remove blood, pigments, water soluble proteins and odour bearing substances. Consequently, the concentration of myofibrillar proteins, which are responsible for improving gel strength and elasticity, increases (Balachandran, 2001). A reduction in water soluble proteins increases the concentrate of myofibrillar proteins, thus enhancing the functional properties of surimi (Park, 2005). The gelling process entails the association of long myofibrillar protein chains which produces a continuous three-dimensional network in which water and other components are trapped. As a result, a viscoelastic gel is obtained (Sanchez-Gonzalez et al., 2008).
In India, mainly fishes of marine origin such as threadfin bream (Nemipterus japonicus), ribbonfish (Trichiurus lepturus) and lizardfish (Saurida tumbil) are being used for surimi production (Muraleedharan et al., 1997). However, with the continuous decrease in marine catch, there is scarcity of raw material for surimi production. On the other hand, inland fish production has increased continuously and pangasius (Pangasianodon hypophthalmus Sauvage, 1878) is one of the species which has very good aquaculture potential and availability throughout the year. Pangasius has white or pale pink flesh and its fillets are characterised by absence of fishy odour, small bones and thin skin. The cooking process results in delicate and firm texture, allowing a wide range of culinary preparations. These characteristics together with its easy availability in market in standard size, make it a suitable species for production of surimi and surimi-based value added products so as to meet the consumer demand (Orban et al., 2008).

In surimi processing, water to mince ratio, washing time and washing cycles are the most important steps. Large amount of water is used in washing to remove the sarcoplasmic proteins, blood, fat and other nitrogenous compounds from the minced fish flesh. It was estimated that approximately 
$80-90 \%$ of the water soluble protein is lost during water washing (Hall, 1994). Texture, colour and odour of the final product are greatly improved when these compounds are removed by washing. The degree of washing required to produce good quality surimi depends on the type, composition and freshness of the fish. The number of washing cycle and water to mince ratio employed for washing may vary among surimi processors. Higher water to mince ratio gives good result for gel strength, but it also increases the cost of production and the amount of waste water as well as it leads to loss of some amount of myofibrillar proteins. According to Lin and Park (1996), solubility of myofibrillar protein increased as the number of washing cycles increased. Hence, the present study was planned to test the suitability of pangasius as an alternative raw material for surimi production and to optimise the method of surimi production from this species which will be useful to the fish processing industries.

\section{Materials and methods}

Raw material preparation

Sutchi catfish (Pangasianodon hypophthalmus), cultured in cages in the Dhasai Reservoir, Thane District, Mumbai was used for the study. Freshly caught fish was iced immediately in a fish to ice ratio of 1:1 and transported to Post Harvest Technology Laboratory, ICAR-Central Institute of Fisheries Education (ICAR-CIFE), Versova, Mumbai within $3 \mathrm{~h}$. Fish was filleted and mince was separated from the fillets, using a deboning machine (Baader 694, Lubek, Germany). The prepared mince was used for surimi preparation using different mince: water ratios.

\section{Surimi preparation}

Minced meat obtained from pangasius, was divided into four lots which were then used to prepare surimi. For this, the minced meat was subjected to water washing using mince:water ratios of 1:1, 1:2, 1:3 and 1:4. Three washing cycles of five minutes each were carried out which included 1 min of stirring and $4 \mathrm{~min}$ of settling. This process of washing was carried out in Hobart mixture unit (Hobert, AE 200, London, England) using chilled water. After each washing, the fat floating on the surface of water was removed manually. The washed meat obtained from these four treatments was then subjected to excess water removal in a basket centrifuge (6:5 Centro fix, Dare, Mumbai, India) at $1200 \mathrm{rpm}$ for $2 \mathrm{~min}$.

\section{Preparation of surimi gels}

Surimi was placed in a mixer, $2.5 \%$ salt was added and then chopped for $1 \mathrm{~min}$ at $4{ }^{\circ} \mathrm{C}$ to obtain a homogeneous sol. The sol was then stuffed into polyvinylidine casing with a diameter of $2.5 \mathrm{~cm}$ and both ends of the casing were sealed tightly. Sols were incubated at $40^{\circ} \mathrm{C}$ for $30 \mathrm{~min}$, followed by heating at $90^{\circ} \mathrm{C}$ for $20 \mathrm{~min}$ in water bath (Benjakul et al., 2003). All gels were cooled in iced water for $20 \mathrm{~min}$ and stored overnight at $4^{\circ} \mathrm{C}$ prior to analyses.

\section{Proximate composition and pH measurement}

Moisture, protein and ash content in prepared surimi samples were determined by standard AOAC methods (AOAC, 2005). Crude fat content was measured as per the method given by Folch et al. (1957). The $\mathrm{pH}$ of the samples was measured using a $\mathrm{pH}$ meter (Hanna Instruments, HI 2211, USA).

\section{Gel strength}

Textural analysis of gels was performed using a texture analyser (Model TA-XT2, Stable Micro Systems, Surrey, UK). Gels were tested at room temperature. Prepared surimi gels were cut into five cylindrical pieces of $2.5 \mathrm{~cm}$ length. The breaking force (gel strength) and deformation (elasticity/ deformability) were measured for each sample by keeping the pieces of each sample into the texture analyser equipped with a spherical plunger $(5 \mathrm{~mm}$ dia $)$. The test conditions were; pre-test speed: $1.0 \mathrm{~mm} \mathrm{sec}^{-1}$; post-test speed: $10.0 \mathrm{~mm}$ $\mathrm{sec}^{-1}$; distance: $4.0 \mathrm{~mm}$; time: $10 \mathrm{sec}$ with $50 \mathrm{~kg}$ load cell. The probe was pressed into the cut surface of gel perpendicularly at a constant speed, until punctured. The force in gram $(\mathrm{g})$ required to puncture into the gel (breaking force) and the distance (in $\mathrm{mm}$ ) at which the probe punctured into the gel (deformation), were recorded. Gel strength for each surimi gel was calculated from respective breaking force and deformation.

\section{Expressible moisture}

Expressible moisture content was measured according to the method of Benjakul et al. (2001) with slight modifications. Gel samples were cut to a thickness of $5 \mathrm{~mm}$, weighed (X) and placed between 3 sheets of Whatman paper no. 4 filter paper at the bottom and 2 sheets on the top of the sample. The standard weight $(5 \mathrm{~kg})$ was placed at the top and held for $2 \mathrm{~min}$. The sample was then removed from the papers and weighed again (Y). Expressible moisture content was calculated using the following equation:

$$
\text { Expressible moisture content }(\%)=\frac{X-Y}{X} \times 100
$$

\section{SDS-PAGE protein pattern}

Protein patterns of prepared surimi were analysed by SDS-PAGE, as per Laemmli (1970). To prepare the protein samples, $27 \mathrm{ml}$ of $5 \%(\mathrm{w} / \mathrm{v})$ SDS solution were added to the sample $(3 \mathrm{~g})$. The mixture was then homogenised using a homogeniser (Polytron, Kinematica, Switzerland) at a speed of $11000 \mathrm{rpm}$ for $2 \mathrm{~min}$ and incubated at $85^{\circ} \mathrm{C}$ for $1 \mathrm{~h}$ to dissolve total proteins. The samples were centrifuged at $3500 \mathrm{~g}$ for $20 \mathrm{~min}$ to remove undissolved debris. Protein 
concentration of the supernatant was determined by the Biuret method (Robinson and Hodgen, 1940) using bovine serum albumin as standard. The sample was then mixed with sample buffer [ $4 \mathrm{ml}$ of $10 \% \mathrm{SDS}, 2 \mathrm{ml}$ of glycerol, $1 \mathrm{ml}$ of $\beta$-mercaptoethanol, $2.5 \mathrm{ml}$ of $0.5 \mathrm{M}$ Tris- $\mathrm{HCl}(\mathrm{pH} 6.8)$ and $0.03 \mathrm{~g}$ bromophenol blue] at 1:1 ratio (v/v). Samples $(20 \mu \mathrm{g}$ proteins) were loaded onto the polyacrylamide gel made of $10 \%$ running gel and $4 \%$ stacking gel and subjected to electrophoresis at a constant current of $15 \mathrm{~mA}$ per gel using a Hoefer Mini Electrophoresis (San Francisco, USA) unit. After separation, the proteins were stained with $0.02 \%(\mathrm{w} / \mathrm{v})$ coomassie brilliant blue R-250 in 50\% (v/v) methanol and $7.5 \%(\mathrm{v} / \mathrm{v})$ acetic acid and destained with $50 \%$ methanol $(\mathrm{v} / \mathrm{v})$ and $7.5 \%(\mathrm{v} / \mathrm{v})$ acetic acid, followed by $5 \%$ methanol $(\mathrm{v} / \mathrm{v})$ and $7.5 \%(\mathrm{v} / \mathrm{v})$ acetic acid.

\section{Folding test}

Folding test was performed as per Lanier (1992). A $3 \mathrm{~mm}$ slice of the gel was subjected to folding test by folding between the thumb and index finger. Depending on the breakage; they were scored as follows: $1=$ Breaks by finger pressure; 2 = Cracks immediately when folded half; $3=$ Crack occurs gradually when folded half; $4=$ No crack occurs after folding half; 5 = No crack occurs after folding twice.

\section{Whiteness}

Whiteness was measured by using Lab scan XE - Colourimeter (Hunter Lab scan XE, U.S.A.) which gives acceptable level of surimi sample based on $\mathrm{L}^{*}, \mathrm{a}^{*}$ and $\mathrm{b}^{*}$ values. Whiteness was calculated as per the following formula:

$$
\text { Whiteness }=100-\left[\left(100-L^{*}\right)^{2}+a^{* 2}+b^{* 2}\right]^{1 / 2}
$$

\section{Sensory evaluation}

Sensory evaluation of surimi sausages was done by 30 untrained panelists, based on method described by Meilgaard et al. (1990) with slight modifications. Sausages were evaluated for appearance, colour, taste, texture, odour and overall liking by the panelists. A nine-point hedonic scale, in which a score of $1=$ not like very much, $5=$ neither like nor dislike and $9=$ like extremely, was used for evaluation. High score indicated good quality and vice versa.

\section{Statistical analysis}

Data were subjected to analysis of variance (ANOVA). Comparison of means was carried out by Duncan's multiple-range tests. Analysis was performed using SPSS package (SPSS 10.0 for Windows, SPSS Inc, Chicago, IL, USA).

\section{Result and discussion}

\section{Yield from whole pangasius}

The yield of surimi prepared using different mince:water ratios is presented in Table 1. From the results, it was observed that surimi yield decreased with increase in mince: water ratio. Increased mince: water ratio resulted in removal of sarcoplasmic proteins, fat, blood and pigments which resulted in decreased yield of surimi. A 52.94\% yield was obtained after fish dressing and a $38.69 \%$ yield of mince was obtained from whole fish after deboning. Separated mince was used for surimi preparation. Depending upon mince: water ratio, surimi yield varied. The yield percentage of surimi obtained with 1:2 mince water ratio was higher in pangasius surimi compared to surimi prepared from tilapia (Ninan et al., 2004). But yield was slightly lower than that reported for major carps (Sankar, 2000). Yathavamoorthi et al. (2012) reported 18.3\% yield with 1:4 mince: water ratio in common carp surimi, which was quite nearer to our findings for pangasius surimi.

Table 1. Yield percentage of surimi prepared from pangasius using different mince: water ratios

\begin{tabular}{llcll}
\hline Parameters & \multicolumn{5}{c}{ Treatments } \\
\hline Mince: water ratio & $1: 1$ & $1: 2$ & $1: 3$ & $1: 4$ \\
${ }^{*}$ Yield (\%) & 28.41 & 24.90 & 24.90 & 24.90 \\
\hline
\end{tabular}

"Based on initial weight of whole fish

\section{Proximate composition}

Higher moisture content was noticed in surimi than in mince which could be due to hydration of protein during the washing process. Proximate composition of surimi is presented in Table 2. The moisture content of mince was $76.50 \%$, which increased with increase in mince: water ratio from 1:1 to 1:4. Observed percentage of protein, fat and ash content of mince was $18.90 \pm 0.00,4.66 \pm 0.65$ and $1.10 \pm 0.01$, respectively, which decreased with increasing mince:water ratio.

In tilapia surimi, moisture content was higher while crude fat, crude protein and ash content were lower with increasing mince:water ratio (Murthy and Rajanna, 2011). Previously, Sanchez-Gozalez et al. (2008) reported a moisture and protein content of sol and gel which were in agreement with the designed formulation of 75.5 and $17 \%$ in Alaska pollock surimi (Grade FA). The results obtained in the present investigation are in agreement with the above findings. The low fat, protein and ash content in the surimi obtained with increased mince:water ratio might be due to removal of those components during washing. 
Table 2. Proximate composition of mince and surimi prepared from Pangasius sp. using different mince: water ratios

\begin{tabular}{lllll}
\hline Sample $^{*}$ & Moisture $\left(\mathrm{g} 100 \mathrm{~g}^{-1}\right)$ & Protein $\left(\mathrm{g} 100 \mathrm{~g}^{-1}\right)$ & Fat $\left({\left.\mathrm{g} 100 \mathrm{~g}^{-1}\right)}^{\text {Ash }\left(\mathrm{g} 100 \mathrm{~g}^{-1}\right)}\right.$ \\
\hline Mince & $75.05 \pm 0.27^{\mathrm{a}}$ & $18.90 \pm 00^{\mathrm{d}}$ & $4.66 \pm 0.65^{\mathrm{c}}$ & $1.10 \pm .01^{\mathrm{b}}$ \\
$1: 1$ & $80.68 \pm 0.40^{\mathrm{b}}$ & $15.94 \pm 0.50^{\mathrm{c}}$ & $3.90 \pm 0.64^{\mathrm{bc}}$ & $0.22 \pm 0.04^{\mathrm{a}}$ \\
$1: 2$ & $81.02 \pm 0.33^{\mathrm{b}}$ & $14.56 \pm 0.90^{\mathrm{bc}}$ & $3.71 \pm 0.35^{\mathrm{bc}}$ & $0.19 \pm 0.02^{\mathrm{a}}$ \\
$1: 3$ & $82.08 \pm 0.33^{\mathrm{b}}$ & $13.10 \pm 1.51^{\mathrm{ab}}$ & $3.15 \pm 3.9^{\mathrm{ab}}$ & $0.18 \pm 0.01^{\mathrm{a}}$ \\
$1: 4$ & $83.84 \pm 1.25^{\mathrm{c}}$ & $12.93 \pm 0.00^{\mathrm{a}}$ & $2.66 \pm 0.62^{\mathrm{a}}$ & $0.18 \pm 0.01^{\mathrm{a}}$ \\
\hline
\end{tabular}

Different superscripts in the same column indicate significant difference $(\mathrm{p}<0.05),(\mathrm{n}=3)$

"All values are expressed on wet weight basis

\section{Gel strength}

Effect of different mince: water ratio on the breaking force and deformation is given in Table 3. Breaking force values of pangasius surimi increased continuously from $323.39 \pm 18.62(\mathrm{~g})$ in mince to $600.20 \pm 47.63(\mathrm{~g})$ in surimi obtained from 1:4 (mince:water ratio). However, deformation values increased continuously with increased mince:water ratio up to $1: 3$ and then decreased to 1:4 (mince:water ratio). Increasing trend was also observed in gel strength with increasing mince:water ratio (Fig.1). The gel strength of washed mince was superior to that of unwashed mince because of the sarcoplasmic protein in unwashed meat which coagulates during the heat setting of salt added sol and does not participate in the formation of gel network. Gel strength was significantly different in surimi obtained with different mince:water ratios. Gel strength of pangasius surimi in the present study was comparatively higher than that of Indian

Table 3. Breaking force and deformation of gels prepared from mince and surimi of pangasius obtained with different mince:water ratios

\begin{tabular}{lll}
\hline Sample & Breaking force $(\mathrm{g})$ & Deformation $(\mathrm{mm})$ \\
\hline Mince & $323.39 \pm 18.62^{\mathrm{a}}$ & $4.99 \pm 0.05^{\mathrm{a}}$ \\
$1: 1$ & $439.64 \pm 20.90^{\mathrm{ab}}$ & $6.94 \pm 2.04^{\mathrm{abc}}$ \\
$1: 2$ & $578.96 \pm 36.20^{\mathrm{b}}$ & $5.68 \pm 0.11^{\mathrm{ab}}$ \\
$1: 3$ & $460.81 \pm 30.20^{\mathrm{ab}}$ & $10.10 \pm 1.45^{\mathrm{c}}$ \\
$1: 4$ & $600.20 \pm 47.63^{\mathrm{c}}$ & $8.66 \pm 2.70^{\mathrm{bc}}$
\end{tabular}

Different superscripts in the same column indicate significant difference $(\mathrm{p}<0.05),(\mathrm{n}=3)$

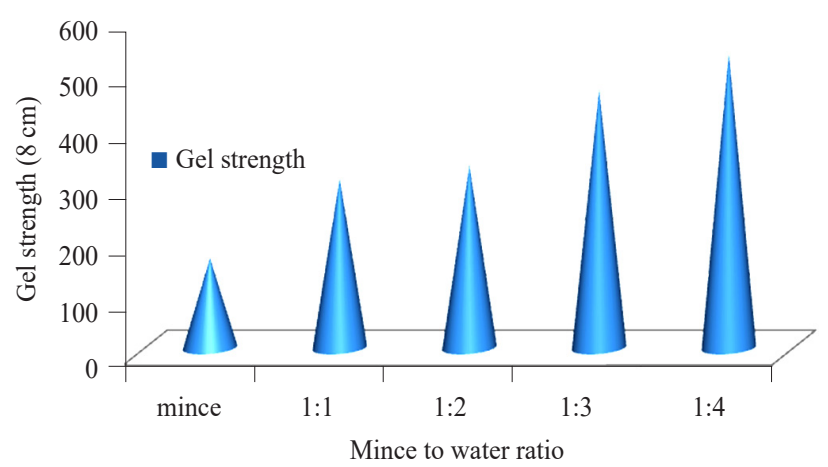

Fig. 1. Gel strength of heat set gels prepared from mince and surimi of pangasius obtained with different mince:water ratios major caprs (IMCs) (Sankar, 2000), but lower than that of tilapia (Ninan et al., 2004).

$p H$

Effect of different mince:water ratio on the $\mathrm{pH}$ of surimi is depicted in Table 4. From the results, it was observed that $\mathrm{pH}$ value of surimi increased significantly $(p<0.05)$ from 6.63 in mince to 6.82 in surimi obtained with mince to water ratio of $1: 4$. Such increase in $\mathrm{pH}$ approaching towards neutrality $(\mathrm{pH}=7.0)$ may be attributed to the washing away of acidic products like lactic acids which might have been produced in the post-mortem fish muscle by the anaerobic glycolysis of glucose.

Table 4. The $\mathrm{pH}$ of mince and surimi of pangasius obtained with different mince: water ratios

\begin{tabular}{llllll}
\hline \multirow{2}{*}{ Mince } & \multicolumn{5}{c}{ Mince: water ratio } \\
\cline { 3 - 6 } & $1: 1$ & $1: 2$ & $1: 3$ & $1: 4$ \\
\hline $\mathrm{pH}$ & $6.63 \pm 0.01^{\mathrm{a}}$ & $6.72 \pm 0.01^{\mathrm{b}}$ & $6.74 \pm 0.05$ & $6.80 \pm 0.08^{\mathrm{c}}$ & $6.82 \pm 0.02^{\mathrm{c}}$ \\
\hline Different supercsripts in the row indicates significant difference $(\mathrm{p}<0.05)$,
\end{tabular}
$(n=3)$

\section{Expressible moisture}

Effect of different mince: water ratio on the expressible moisture of surimi gel is given in Table 5. From the results, it was observed that there was inverse relationship of expressible moisture with gel strength of surimi, i.e., higher the gel strength, lower the expressible moisture. The lowest expressible moisture was found in mince water ratio of 1:4 which correlated with the maximum gel strength. This is in accordance with increased gel strength of surimi with increase in mince: water ratio and number of washing cycles. A good surimi gel is a three dimensional network of myofibrillar protein stabilised by various covalent and non-covalent bands and water is entrapped in it. If the gel is weak, higher expressible moisture will be found and vice-versa. Expressible moisture is found to increase as the amount of entrapped water decreased (Ramirez et al., 2007). Lowest percentage of water extracted means highest water holding capacity.

\section{Whiteness}

Effect of different mince:water ratio on the whiteness values of pangasius surimi before and after heat setting are 
Table 5. Expressible moisture of mince and surimi of pangasius obtained with different mince:water ratios

\begin{tabular}{llllll}
\hline \multirow{2}{*}{ Mince } & \multicolumn{4}{c}{ Mince: water ratio } & \\
\cline { 2 - 5 } & & $1: 1$ & $1: 2$ & $1: 3$ & $1: 4$ \\
\hline Expressible moisture & $22.92 \pm 1.92^{\mathrm{d}}$ & $17.85 \pm 0.35^{\mathrm{c}}$ & $13.06 \pm 1.44^{\mathrm{b}}$ & $10.50 \pm 1.02^{\mathrm{a}}$ & $8.60 \pm 1.05^{\mathrm{a}}$ \\
\hline
\end{tabular}

Different letters in the row indicate significant difference $(\mathrm{p}<0.05),(\mathrm{n}=3)$

depicted in Table 6a,b and Fig. 2 respectively. From the results, it was observed that whiteness values increased continuously with increase in mince:water ratio up to 1:4. This is very well correlated with reduced redness values, i.e., $\mathrm{a}^{*}$ with increased mince:water ratio. Highest values of whiteness were observed in surimi after setting. More mince: water ratio resulted in the removal of most of the pigment, blood and impurities and improved the whiteness of surimi. Alaska pollock surimi comparatively had higher whiteness (Jin et al., 2007). For surimi processing, myoglobin plays an important role in the whiteness (Chen et al., 1997), which is one of the most important factors in determining the quality of surimi (Jin et al., 2007). Whiteness of surimi in the present study was comparatively similar to that of big snapper surimi (Julavittayanukul et al., 2006).

Table 6a. Whiteness of mince and surimi of pangasius obtained with different mince:water ratios

\begin{tabular}{llll}
\hline Sample & $\mathrm{L}^{*}$ & $\mathrm{a}^{*}$ & $\mathrm{~b}^{*}$ \\
\hline Mince & $45.57 \pm 0.13^{\mathrm{a}}$ & $16.13 \pm 1.14^{\mathrm{c}}$ & $19.69 \pm 0.77^{\mathrm{a}}$ \\
$1: 1$ & $60.53 \pm 0.48^{\mathrm{b}}$ & $6.74 \pm 0.544^{\mathrm{b}}$ & $23.48 \pm 0.48^{\mathrm{cd}}$ \\
$1: 2$ & $64.68 \pm 0.79^{\mathrm{c}}$ & $4.91 \pm 1.00^{\mathrm{a}}$ & $23.81 \pm 2.01^{\mathrm{d}}$ \\
$1: 3$ & $64.70 \pm 0.74^{\mathrm{c}}$ & $5.25 \pm 0.35^{\mathrm{a}}$ & $21.68 \pm 0.0 .53^{\mathrm{bc}}$ \\
$1: 4$ & $64.59 \pm 0.86^{\mathrm{c}}$ & $4.64 \pm 0.46^{\mathrm{a}}$ & $20.89 \pm 0.33^{\mathrm{ab}}$ \\
\hline
\end{tabular}

Different superscripts in the same column indicate significant difference $(\mathrm{p}<0.05),(\mathrm{n}=3)$

Table $6 \mathrm{~b}$. Whiteness of heat set gels prepared from mince and surimi of pangasius obtained with different mince:water ratios

\begin{tabular}{llll}
\hline Sample & $\mathrm{L}^{*}$ & $\mathrm{a}^{*}$ & $\mathrm{~b}^{*}$ \\
\hline Mince & $65.70 \pm 0.34^{\mathrm{a}}$ & $5.24 \pm 0.48^{\mathrm{c}}$ & $19.77 \pm 0.19^{\mathrm{b}}$ \\
$1: 1$ & $75.47 \pm 0.52^{\mathrm{b}}$ & $1.27 \pm 0.29^{\mathrm{b}}$ & $18.18 \pm 1.62^{\mathrm{ab}}$ \\
$1: 2$ & $76.52 \pm 0.37^{\mathrm{c}}$ & $0.96 \pm 0.48^{\mathrm{ab}}$ & $17.11 \pm 1.78^{\mathrm{a}}$ \\
$1: 3$ & $77.51 \pm 0.29^{\mathrm{d}}$ & $0.53 \pm 0.32^{\mathrm{a}}$ & $16.95 \pm 1.08^{\mathrm{a}}$ \\
$1: 4$ & $78.86 \pm 0.35^{\mathrm{e}}$ & $0.31 \pm 0.28^{\mathrm{a}}$ & $16.20 \pm 0.62^{\mathrm{a}}$
\end{tabular}

Different superscripts in the same column indicate significant difference $(\mathrm{p}<0.05),(\mathrm{n}=3)$

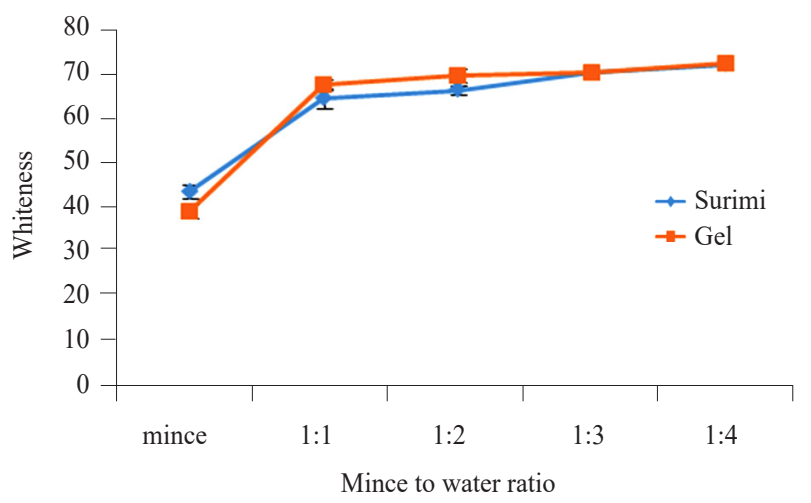

Fig. 2. Whiteness of surimi and heat set gels prepared from mince and surimi of pangasius obtained with different mince:water ratios

\section{Folding test}

Scores of folding test for surimi obtained with different mince:water ratios are given in Table 7. It was found that mince sample had the lowest folding test score of 1.40 , compared to surimi obtained from 1:3 and 1:4 mince:water ratios respectively. This is in accordance with the higher gel strength and lower expressible moisture in the surimi obtained with high mince:water ratio. Folding test is very subjective and can be considered as a preliminary test to differentiate high and low grade surimi. However, it lacks the sensitivity to distinguish different functional properties of surimi such as gel strength (Reppond et al., 1987).

\section{SDS-PAGE protein pattern}

Effect of varying levels of mince:water ratio on the protein pattern of surimi is elucidated in Fig. 3. It can be seen that myosin and actin are the two major myofibrillar proteins in the mince and surimi obtained with varying levels of mince:water ratio. Myosin heavy chain (MHC) band intensity increased in the surimi obtained with 1:3 and 1:4 ratio (mince: water), compared with other treatments. Further, it can be seen in Fig. 4. that the MHC band intensity reduced in gels of all surimi samples after heating. Nevertheless, MHC band intensity of surimi gels, obtained from 1:3 and 1:4 mince:water ratios, disappeared almost completely

Table 7. Mean scores of folding test of heat set gels prepared from mince and surimi of pangasius obtained with different mince:water ratios

\begin{tabular}{llllll}
\hline \multicolumn{7}{c}{ Mince: water ratio } \\
\hline Parameter & Mince & $1: 1$ & $1: 2$ & $1: 3$ & $1: 4$ \\
\hline Folding test & $1.40 \pm 0.54^{\mathrm{a}}$ & $2.20 \pm 0.44^{\mathrm{b}}$ & $2.40 \pm 0.54^{\mathrm{b}}$ & $3.40 \pm .54^{\mathrm{c}}$ & $3.60 \pm 0.54^{\mathrm{c}}$ \\
\hline
\end{tabular}

Different superscripts in the row indicate significant difference $(\mathrm{p}<0.05),(\mathrm{n}=3)$ 
indicating very good polymerisation. The results correlate well with the high breaking force and deformation in surimi gel obtained from 1:3 and 1:4 mince:water ratios. The SDSPAGE pattern of total protein revealed multiple bands in the high and low molecular weight ranges. Thick bands are $\mathrm{MHC}$ and actin, which correspond to high molecular weight of myofibrillar proteins. The electrophoretic pattern of Fig. 3 and 4 showed clear difference between unwashed and washed mince with respect to high and low molecular weight proteins. After washing, low molecular weight protein were lost. Myosin heavy chain concentration increased with increasing mince:water ratio. The loss of myofibrillar protein increased with increasing mince:water ratio (Park and Lin., 2005). The higher MHC band intensity in surimi obtained with high mince:water ratios is in accordance with higher gel strength of the same.

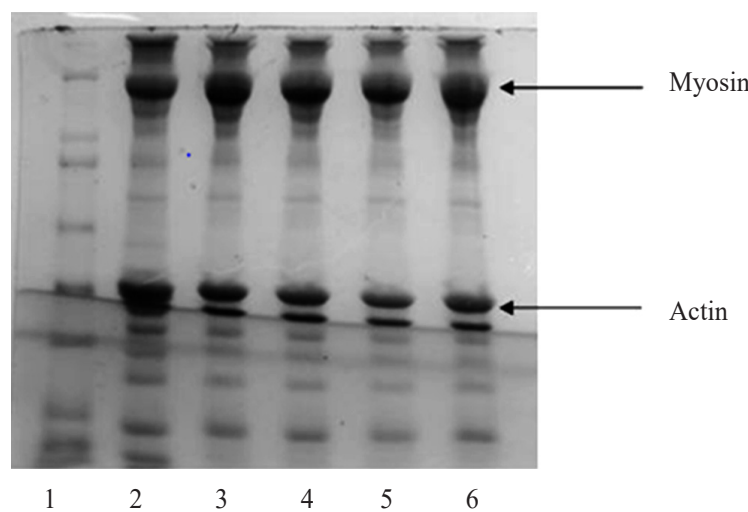

Fig. 3. SDS-PAGE pattern of proteins from mince and surimi of pangasius obtained with different mince:water ratios Lane 1 - marker, Lane 2 - mince and Lane 3-6 - surimi obtained with mince:water ratio of 1:1 to $1: 4$

\section{Sensory evaluation}

Sensory evaluation of prepared surimi with different mince:water ratio by demerit scale system showed acceptability of surimi from different treatments. Improved colour, appearance, odour, texture and overall acceptability were observed due to increasing mince:water ratio (Table 8).

Among the different mince:water ratios, 1:3 and 1:4 were found to be better since they gave very high gel strength to the surimi as compared to other treatments. Nevertheless, yield of surimi was higher in 1:3 compared to 1:4 ratio. Therefore, from the results, it can be concluded that a mince:water ratio of 1:3 is ideal for obtaining a good quality surimi from pangasius.

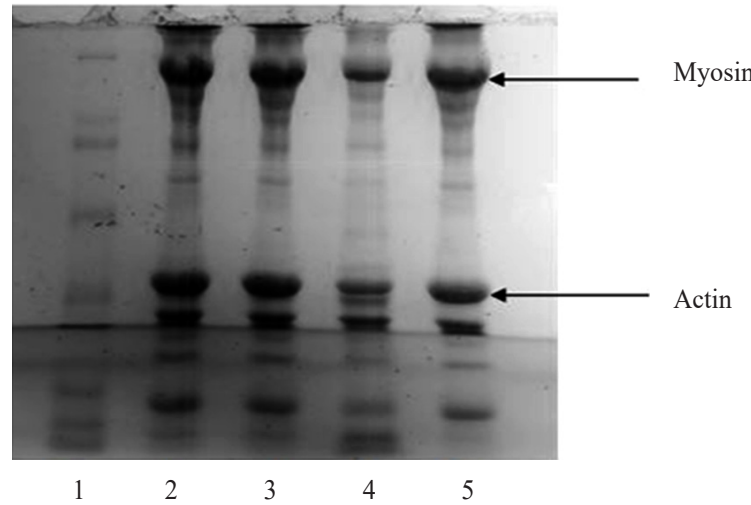

Fig.4. SDS-PAGE pattern of proteins from heat set gels of surimi of pangasius obtained with different mince:water ratios Lane 1 - marker, Lane 2 - 5 - gel obtained with mince:water ratio of $1: 1$ to $1: 4$

Table 8. Mean sensory scores of heat set gels prepared from mince and surimi of pangasius obtained with different mince:water ratios

\begin{tabular}{llllll}
\hline $\begin{array}{l}\text { Treatments } \\
\text { (Mince:water ratio) }\end{array}$ & \multicolumn{5}{c}{ Attributes } \\
\cline { 2 - 6 } & Colour & Appearance & Odour & Texture & Over all \\
\hline $1: 1$ & $5.00 \pm 1.73^{\mathrm{a}}$ & $5.40 \pm 0.54^{\mathrm{a}}$ & $5.20 \pm 1.30^{\mathrm{a}}$ & $5.40 \pm 1.51^{\mathrm{a}}$ & $5.20 \pm 0.83^{\mathrm{a}}$ \\
$1: 2$ & $5.80 \pm 1.64^{\mathrm{ab}}$ & $6.60 \pm 0.54^{\mathrm{b}}$ & $6.10 \pm 1.24^{\mathrm{ab}}$ & $6.00 \pm 1.41^{\mathrm{ab}}$ & $6.20 \pm 0.83^{\mathrm{b}}$ \\
$1: 3$ & $7.40 \pm 0.54^{\mathrm{bc}}$ & $7.2 \pm 0.83^{\mathrm{b}}$ & $6.90 \pm 0.89^{\mathrm{bc}}$ & $7.00 \pm 0.70^{\mathrm{b}}$ & $8.00 \pm 1.22^{\mathrm{c}}$ \\
$1: 4$ & $8.80 \pm 0.44^{\mathrm{c}}$ & $8.60 \pm 0.54^{\mathrm{c}}$ & $8.00 \pm 1.00^{\mathrm{c}}$ & $8.00 \pm 0.70^{\mathrm{c}}$ & $8.00 \pm 1.22^{\mathrm{c}}$ \\
\hline
\end{tabular}

Different superscripts in the same column indicate significant difference $(\mathrm{p}<0.05),(\mathrm{n}=3)$

\section{Acknowledgements}

The authors are grateful to the Director and Vice Chancellor of ICAR-CIFE, Mumbai for granting permission to carry out the work and for providing necessary facilities.

\section{References}

AOAC 2005. Official methods of analysis, $18^{\text {th }}$ edn. Association of Official Analytical Chemists, AOAC International Suite 500 481, North Frederick Avenue Gaithersburg, Maryland, USA.
Balachandran, K. K. 2001. Post-harvest technology of fish and fish products, Daya Publishing House, New Delhi, 440 pp.

Benjakul, S., Visessanguan, W. and Tueksuban, J. 2003. Changes in physico-chemical properties and gel-forming ability of lizardfish (Saurida tumbil) during post-mortem storage in ice. Food Chem., 80(4): 535-544.

Benjakul, S., Visessanguan, W., Ishizaki, S. and Tanaka, M. 2001. Differences in gelation characteristics of natural actomyosin 
from two species of bigeye snapper, Priacanthus tayenus and Priacanthus macracanthus. J. Food Sci., 66: 1311-1318.

Chen, H. H., Chiu, E. M. and Huang, J. R. 1997. Colour and gel forming properties of horse mackerel (Trachurus japonicus) as related to washing conditions. J. Food. Sci., 62(5): 985-991.

Folch, J., Lees. M. and Sloane-Stanley, G. 1957. A simple method for the isolation and purification of total lipids from animal tissues. J. Biol. Chem., 226: 497-509.

Hall, G. M. 1994. Fish processing technology, Blackia Academic and Professional, UK, p. 72-87.

Jin, S. K., Kim, I., Kim, S., Jeong, K., Choi, Y. and Hur, S. 2007. Effect of muscle type and washing times on physico-chemical characteristics and qualities of surimi. J. Food. Eng., 81(3): 618-623.

Julavittayanukul, O., Benjakul, S. and Visessanguan, W. 2006. Effect of phosphate compounds on gel-forming ability of surimi from bigeye snapper (Priacanthus tayenus). Food Hydrocolloids, 20: 1153-1163.

Laemmli, U. K. 1970. Cleavage of structural proteins during the assembly of the head of bacteriophage T4. Nature, 227(5259): 680-685.

Lanier, T. C. 1992. Measurement of surimi composition and functional properties. In: Lanier, T. C. and Lee, C. M. (Eds.), Surimi process technology, Marcel Decker Inc., New York, p. 123-166.

Lee, C. M. 1986. Surimi manufacturing and fabrication of surimi based products. Food Technol., 40(3): 115-124.

Lin, T. M. and Park, J. W. 1996. Protein solubility in Pacific whiting affected by proteolysis during storage. J. Food Sci., 61: $536-539$

Meilgaard, M. C., Carr, B. T. and Civille, G. V. 2006. Sensory evaluation techniques, $4^{\text {th }}$ edn. CRC Press.

Muraleedharan, V., Antony, K. P., Perigreen, P. A. and Gopakumar, K. 1997. Surimi from five Indian fish species. Trop. Sci., 37: $99-102$.

Murthy, L. N. and Rajanna, K. B. 2011. Effect of washing on composition and properties of proteins from tilapia (Oreochromis mossambicus) meat. Fish Technol., 48(2): 125-132.
Ninan, G., Bindu, J. and Joseph, J. 2004. Properties of washed mince (surimi) from fresh and chill stored Black Tilapia, Oreochromis mossambicus. Fish Technol., 41(1): 21-28.

Ofstad, R., Grahl-medsen, E. and Solberg, I. 1990. Utilisation of herring (Clupea harengus) and cod (Gadus morhua) fillet waste for the production of surimi based products. I.I.F-I.I.R-Commission C2. Aberdeen (UK), 3: 21-27.

Orban, E., Nevigato, T., Lena, G. D., Masci, M., Casini, I., Gambelli, L. and Caproni, R. 2008. New trends in the seafood market. Sutchi catfish (Pangasius hypophthalmus) fillets from Vietnam: Nutritional quality and safety aspects. Food Chem., 110: 383-389.

Park, J. W. and Lin, T. J. 2005. Surimi: manufacturing and evaluation. In: Park, J. W. (Ed.) Surimi and surimi seafood. $2^{\text {nd }}$ edn., Taylor and Francis, Boca Raton, p. 33-40.

Ramirez, J. A., Velazquez, G., Echevarria, G. L. and Torres, J. A. 2007. Effect of adding insoluble solids from surimi wash water on the functional and mechanical properties of pacific whiting grade A surimi. Bioresource Technol., 98: 2148-2153.

Reppond, K. D., Edson, S. A., Babbitt, J. K. and Hardy, A. 1987. Observations on the functional properties of U. S. landprocessed surimi. J. Food Sci., 52(2): 505-506.

Robinson, H. W. and Hogden, C. G. 1940. The biuret reaction in the determination of serum proteins 1 . A study of the conditions necessary for the production of a stable colour which bears a quantitative relationship to the protein concentration. J. Biol. Chem., 135: 707-725.

Sanchez-Gonzalez, I., Carmona, P., Moreno, P., Borderias, J., Sanchez-Alonso, I., Rodriguez-Casado, A. and Careche, M. 2008. Protein and water structural changes in fish surimi during gelation as revealed by isotopic H/D exchange and Raman spectroscopy. Food Chem., 106: 56-64.

Sankar, T. V. 2000. Biochemical and storage characteristic of myofibrillar protein (surimi) from freshwater major carp. $\mathrm{Ph}$. D. Thesis. Cochin University of Science and Techniology, $162 \mathrm{pp}$.

Yathavamoorthi, R., Sankar, T. V. and Ravishankar, C. N. 2012 Effect of ice storage on the characteristics of common carp surimi. Fish. Technol., 49: 38-44. 